\title{
Sealing of sand using spraying and percolating biogrouts for the construction of model aquaculture pond in arid desert
}

\author{
Viktor Stabnikov $\cdot$ Volodymyr Ivanov $\cdot$ Jian Chu
}

Received: 2 February 2016/ Accepted: 30 May 2016/Published online: 9 June 2016

(C) The Author(s) 2016. This article is published with open access at Springerlink.com

\begin{abstract}
The topic of the paper is the biotechnological sealing of sand using calcium- or iron-based biogrouts. These processes are modeling the sealing of sand during construction of aquaculture pond in the arid desert. The experiments showed that it is possible to conduct biosealing of sand using microbially induced calcium carbonate precipitation performed by the spraying of dead but urease-active bacteria. The sealing was also effective due to ferric hydroxide precipitation in sand after percolation of ferrous-containing solution produced from iron ore and cellulose by the community of acidogenic and iron-reducing bacteria. These treatments of sand can decrease its hydraulic conductivity from the level of $10^{-4} \mathrm{~m} / \mathrm{s}$ to the level of $10^{-8} \mathrm{~m} / \mathrm{s}$, which is an acceptable level for the aquaculture ponds. The cost of this sealing, especially when the local sources of calcium chloride brain or low grade iron (hydr)oxides of iron ore are applied, could be several times lower than any other known methods of the sand sealing, and could be used in aquaculture practice for the construction of fish, prawns, or algae ponds in sand of the arid deserts.
\end{abstract}

Keywords Aquaculture pond - Biosealing of sand - Microbially induced calcium carbonate precipitation . Microbially induced ferric hydroxide precipitation

\section{Introduction}

Non-arable land in an arid desert can be used for algae, fish, and prawns pond cultures (Winckelmann et al. 2015) but the problem is the high cost of the sealing a pond constructed in sandy soil. Potential solution of this problem can be a biosealing of sand as shown in this paper. A new scientific and engineering discipline, Construction Biotechnology, is the development of the microbially mediated construction processes and construction biomaterials (Ivanov et al. 2015; Stabnikov et al. 2015). The new type of construction materials, biocement and biogrouts, are developing extensively as an alternative to cement and chemical grouts (Bachmeier et al. 2002; Ferris et al. 1996; Whiffin et al. 2007; Ivanov and Chu 2008; DeJong et al. 2010; De Muynck et al. 2010; Burbank et al. 2011, 2012; Stabnikov et al. 2011; Al-Thawadi and Cord-Ruwisch 2012; Chu et al. 2012; Rong et al. 2012) because they have low viscosity, can penetrate deeper into porous soil, and usually are less harmful for environment than conventional grouts.

V. Stabnikov $\cdot$ V. Ivanov $(\bowtie) \cdot$ J. Chu

School of Civil and Environmental Engineering, Nanyang Technological University, 50 Nanyang Avenue,

Singapore 639798, Singapore

e-mail: cvivanov@ntu.edu.sg 
Biocementation and biosealing of sand could be based on microbially induced calcium carbonate or ferric hydroxide precipitation due to the activity of urease-producing bacteria (UPB) in the presence of urea and ions of calcium or ferrous:

$$
\begin{gathered}
\mathrm{Ca}^{2+}+\left(\mathrm{NH}_{2}\right)_{2}+2 \mathrm{H}_{2} \mathrm{O} \rightarrow \mathrm{CaCO}_{3} \downarrow+2 \mathrm{NH}_{4}^{+} \\
\mathrm{Fe}^{2+}+0.25 \mathrm{O}_{2}+4 \mathrm{H}^{+}+3\left(\mathrm{NH}_{2}\right)_{2} \mathrm{CO}+5.5 \mathrm{H}_{2} \mathrm{O} \rightarrow \mathrm{Fe}(\mathrm{OH})_{3} \downarrow+6 \mathrm{NH}_{4}^{+}+3 \mathrm{CO}_{2}
\end{gathered}
$$

To produce solution of ferrous ions, organic acids must be produced by acidogenic bacteria fermenting cellulose at the first step as shown below (molar ratios of volatile fatty acids were taken from Madigan et al. 2014):

$$
\mathrm{C}_{6} \mathrm{H}_{12} \mathrm{O}_{6}+0.82 \mathrm{H}_{2} \mathrm{O} \rightarrow 1.13 \mathrm{CH}_{3} \mathrm{COOH}+0.35 \mathrm{C}_{2} \mathrm{H}_{5} \mathrm{COOH}+0.26 \mathrm{C}_{3} \mathrm{H}_{7} \mathrm{COOH}+1.67 \mathrm{CO}_{2}+2.47 \mathrm{H}_{2}
$$

where $\mathrm{C}_{6} \mathrm{H}_{12} \mathrm{O}_{6}$ is a monomer of cellulose, and $\mathrm{CH}_{3} \mathrm{COOH}, \mathrm{C}_{2} \mathrm{H}_{5} \mathrm{COOH}$, and $\mathrm{C}_{3} \mathrm{H}_{7} \mathrm{COOH}$ are acetic, propionic, and butyric acids, respectively. Then, iron ore should be reduced by iron-reducing bacteria using organic acids, mainly acetate:

$$
8 \mathrm{Fe}^{3+}+\mathrm{CH}_{3} \mathrm{COOH}+2 \mathrm{H}_{2} \mathrm{O} \rightarrow 8 \mathrm{Fe}^{2+}+4 \mathrm{CO}_{2}+8 \mathrm{H}^{+}
$$

Urease-producing bacteria for biocementation/biosealing of sand should be able to synthesize active urease under alkaline environment with high concentration of salts (Stabnikov et al. 2013), should show low aggregation ability at high concentration of calcium ions (DeJong et al. 2006; Stabnikov et al. 2011), and should be biological safe, e.g., non-pathogenic ones. Usually, the strains of Sporosarcina pasteurii, formerly Bacillus pasteurii, are commonly used for biocementation (Bang et al. 2001; Bachmeier et al. 2002; Whiffin 2004; Whiffin et al. 2007; Dupraz et al. 2006; Mortensen and DeJong 2011; Tobler et al. 2014).

These bacteria belong to Risk group 1 with low individual and community risk. However, there are a lot of studies when such opportunistic pathogens as Bacillus cereus (Maheswaran et al. 2014), Bacillus mycoides (Elmanama and Alhour 2013), Proteus sp., Proteus vulgaris or Proteus mirabilis (Dosier 2014; Khanafari et al. 2011; Whiffin 2004; Varalakshmi 2014), Staphylococcus aureus and Klebsiella pnemoniae (Varalakshmi 2014), and even pathogenic bacteria Helicobacter pylori (Dosier 2014) were proposed to be used for biocementation. So, the critical point of biocementation is an introduction of live bacterial cells in environment, which is a risk.

In our previous research on the sand biosealing, we used live urease-producing bacteria for the construction of the model aquaculture pond using sealing of sand by microbially induced calcium carbonate precipitation (Stabnikov et al. 2011; Chu et al. 2013). The aim of the present study was to check possibility to seal the pond in sand using calcium or iron salts and dead but urease-active cells of urease-producing bacteria to ensure biosafety of the process for human and environment.

\section{Materials and methods}

The main idea of the safe biosealing using spaying was to kill cells of UPB in such way that their urease activity will remain intact. However, experiments with existing strains of Sporosarcina pasteurii/Bacillus pasteurii did not produce such results probably because of ability of these bacteria to produce stable spores and due to thick cell wall. Therefore, another strain of UPB was isolated and tested. The strain of nonsporogenic Yaniella sp. VS8 (GenBank accession number of nucleotide sequence of 16S rRNA is KT182991), belongs to Actinobacteria, the phyla Bacteria and represents Gram-positive bacteria with a high $\mathrm{G}+\mathrm{C}$ content

in their DNA, the order Micrococcales, the family Micrococcaceae, was isolated from enrichment culture of UPB that was used in practice for several years. The bacteria of the genus Yaniella belong to Risk group 1. 
The strain Yaniella sp. VS8 demonstrated a high enough urease activity, so application of its inactivated cells for biocementation was studied.

Batch cultivation of Yaniella sp. VS8 was provided under shaking at $200 \mathrm{rpm}$ at temperature $25{ }^{\circ} \mathrm{C}$. Medium for microbial cultivation had the following composition: Tryptic Soya Broth DIFCO ${ }^{\mathrm{TM}}, 20 \mathrm{~g} ; \mathrm{NaCl}$, $20 \mathrm{~g}, \mathrm{NiCl}_{2} \bullet 6 \mathrm{H}_{2} \mathrm{O}, 24 \mathrm{mg}$, phenol red, $10 \mathrm{mg}$, distilled water $1 \mathrm{~L}, \mathrm{pH}$ 8.2. This medium was sterilized at $121{ }^{\circ} \mathrm{C}$ for $15 \mathrm{~min}$. Stock solution of urea, $100 \mathrm{~g} / \mathrm{L}$, was sterilized by filtration through Millipore filter with diameter $0.2 \mu \mathrm{m}$ to avoid urea loss due to thermal treatment. $200 \mathrm{~mL}$ of urea stock solution was added to $800 \mathrm{~mL}$ of described above medium, and this urea-containing medium was used for bacteria cultivation (TSB medium).

Treatment of bacterial cells (culture liquid of strain VS8) was done by addition of $0.5 \%$ (w/v) sodium dodecyl sulfate (SDS) for $960 \mathrm{~min}$. Bacterial biomass was separated by centrifugation at $4{ }^{\circ} \mathrm{C}$ and $10,000 \mathrm{rpm}$ for 10 min using Micro Cooling Centrifuge 5922 (Kubota, Japan), resuspended in $\mathrm{NaCl}, 2 \%$, and used for biocementation of sand.

To determine the concentration of cells in bacterial suspensions, the enumeration of colony forming units (CFU) was done after spread-plate inoculation of the Petri plates aseptically filled with Tryptic Soy Agar (TSA) (DIFCO, Lawrence, USA) by $0.1 \mathrm{~mL}$ of the serial tenfold dilutions of the bacterial suspension. To check the content of live bacterial cells in biocemented sand, $0.1 \mathrm{~g}$ of sand was mixed with $10 \mathrm{~mL}$ of solution $\mathrm{NaCl}, 2 \%$, and after vortexing, this suspension was used for spreading onto solid medium in the Petri dishes. The enumeration of $\mathrm{CFU}$ was made after incubation of inoculated Petri plates at $30{ }^{\circ} \mathrm{C}$ for 5 days.

Urease activity was defined as the amount of ammonium produced from $1 \mathrm{M}$ solution of urea per minute. Amount of ammonium produced from urea was determined using electric conductometer showing linear correlation $\left(R^{2}=0.9997\right)$ between the molar concentrations of $\mathrm{NH}_{4}{ }^{+}(Y)$ and the changes of electric conductivity of solutions $(\Delta \mathrm{X})$ in $\mathrm{mS} / \mathrm{cm}$.

The hydraulic conductivity of sand, $k$, in the model pond was measured by falling head method at water head falling from 5 to $2 \mathrm{~cm}$ according to the equation:

$$
k=V / t \cdot S(m / s),
$$

where $V$ is the volume of water passed through the sand, $t$ is a time of the liquid was passed through the sand, and $S$ is a cross-sectional area of water flow through sand.

A standard sand ASTM C778 was used for the experiments. This rounded grain silica sand had a mean grain size of $0.42 \mathrm{~mm}$. The specific gravity was 2.65 . Sand, total $6 \mathrm{~kg}$, was placed into the plastic box with the sizes: $260 \mathrm{~mm}$ in width, $360 \mathrm{~mm}$ in length, and $55 \mathrm{~mm}$ in height.

Construction of the model pond using sand biocementation comprised with the steps of the formation of the bottom and the walls in sand: sand, $4.5 \mathrm{~kg}$, was placed in the box, and then 4 plastic sheets were fixed into sand for the formation of walls. Sand, $1.5 \mathrm{~kg}$, was spread between the walls of plastic box and plastic sheets to form the walls of pond.

Biosealing with $\mathrm{CaCO}_{3}$ was done by spaying of the bacterial suspension and the solution of $\mathrm{CaCl}_{2}$ and urea. Bacterial suspension was spread onto the surface of the model pond and left for $30 \mathrm{~min}$. Then, mixture of the

$$
7.6 \pm 1.9 \mathrm{~mm}
$$

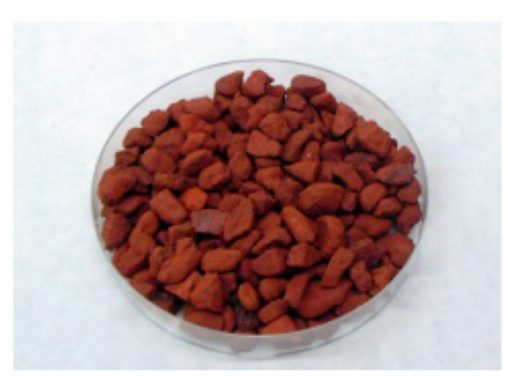

$2.4 \pm 0.4 \mathrm{~mm}$

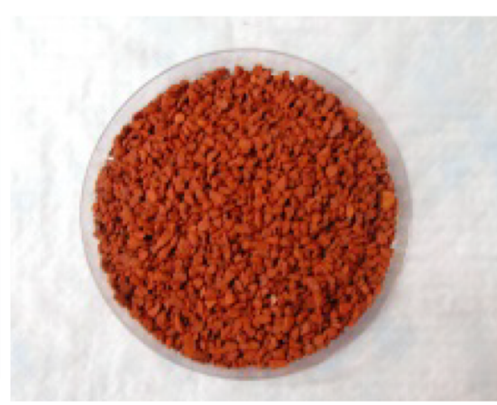

$0.6 \pm 0.1 \mathrm{~mm}$

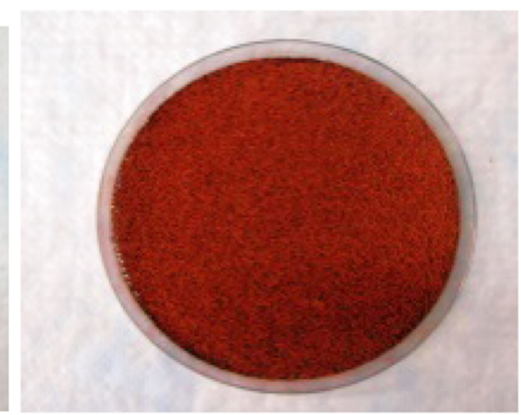

Fig. 1 Iron ore particles of different sizes 
solutions of calcium chloride and urea was spread onto the sand surface and left for $16 \mathrm{~h}$. Spray of the mixture was done some times for each treatment, thus the sand was not submerged into liquid. The treatments were repeated 11 times. After 8th, 9th, and 10th treatments, the model pond was dried by placing in oven at $60{ }^{\circ} \mathrm{C}$ : after 8 and 9 treatments for night; after 10th treatment or $2 \mathrm{~h}$. The study period included: (1) biotreatment15 days, (2) drying on air-60 days, (3) additional biotreatment -4 days; (4) washing with water-3 days.

The production of dissolved ferrous ions was done by consortium of cellulose-fermenting and iron-reducing bacteria producing sealing solution in the 3-L plastic bottle filled with $400 \mathrm{~mL}$ of tap water, $50 \mathrm{~mL}$ of anaerobic sludge from local municipal wastewater treatment plant, $1 \mathrm{~kg}$ of beach sand, $100 \mathrm{~g}$ of the particles of hematite iron ore (ferric oxide) with average size of $2.4 \pm 0.4 \mathrm{~mm}$ (Fig. 1), $30 \mathrm{~g}$ of cellulose (shredded paper tissue), and $20 \mathrm{~g}$ of $\mathrm{CaCO}_{3}$ for $\mathrm{pH}$ buffering.

Cultivation was done for $20-45$ days at $25^{\circ} \mathrm{C}$ and was stopped when concentration of $\mathrm{Fe}^{2+}$ was above $0.5 \mathrm{~g} / \mathrm{L}$. Then, $300 \mathrm{~mL}$ of ferrous-containing solution and $50 \mathrm{~mL}$ of $0.05 \mathrm{M}$ solution of urea altogether with $50 \mathrm{~mL}$ of UPB bacterial suspension were added to the $5-\mathrm{cm}$ diameter plastic column filled with $650 \mathrm{~g}$ of sand for 3 days incubation. Then, solution was drained and the same treatment was repeated. There were 11 such treatments for the sand clogging.

\section{Results and discussion}

Biosealing of sand with calcium carbonate

The best way to ensure biosafety of the aquaculture pond biosealing could be killing of bacterial cells and application of dead bacterial cells, because application of enzyme urease for large-scale biocementation could be too expensive and probably the presence of bacterial cells is needed to create crystallization centers for calcium carbonate precipitation on sand surface (Stocks-Fischer et al. 1999; Gat et al. 2014).

Killing of bacterial cells Yaniella sp. VS8 was done with sodium dodecyl sulfate (SDS) added to culture liquid to concentration $0.5 \%(\mathrm{w} / \mathrm{v})$ for $960 \mathrm{~min}$. SDS, $\mathrm{C}_{12} \mathrm{H}_{25} \mathrm{NaO}_{4} \mathrm{~S}$, is an anionic surfactant inhibiting growth of many Gram-positive (Flahaut et al. 1996) and Gram-negative bacteria (Woldringh and Van Iterson 1972; Adamowicz et al. 1991) via dissolution of the cell membrane (Kramer et al. 1984; Hansen et al. 2011). Concentration of live bacterial cells and urease activity (UA) of bacterial suspension were determined in the samples after treatment and were compared with control (Table 1).

Bacterial cells were killed, but urease activity of culture liquid after treatment remained at the level of $4.9 \mathrm{mM}$ hydrolyzed urea/min, while this level before treatment was $5.6 \mathrm{mM}$ hydrolyzed urea/min.

Totally, 2 L of treated bacterial suspension containing 5.8-g dry biomass, $108 \mathrm{~g}$ of calcium, and $225 \mathrm{~g}$ of urea was used for biosealing of the model pond by spraying onto the sand surface with area of $722.5 \mathrm{~cm}^{2}$. Finally, after eleven biotreatments the model pond with sizes $180 \times 275 \times 25 \mathrm{~mm}$ was constructed (Fig. 2).

Calcium in effluent was absent after every treatment. Due to this treatment, the hydraulic conductivity of sand was decreased from $5.2 \times 10^{-4}$ to $7.7 \times 10^{-9} \mathrm{~m} / \mathrm{s}$. Quantity of water percolated through pond bottom sand layer for the testing pond and control per day vs duration of study period is shown in Fig. 3. It was changed from 7000 to $96 \mathrm{~mm} /$ day.

Effect of water depth on the hydraulic conductivity was measured by the water seepage from 8-mm diameter plastic tube connected with the bottom. Average values of the seepage for the layers of biocemented sand and not cemented sand at water head 500-1000 mm were 96 and about $7000 \mathrm{~mm} /$ day. The hydraulic conductivity of the biosealing layer in tap water did not changed for at least 90 days.

Table 1 Concentration of live bacterial cells and UA of bacterial suspensions

\begin{tabular}{llcc}
\hline Object & \multicolumn{1}{l}{ UA, mM hydrolyzed urea/min for contact time with urea solution } & CFU/mL \\
\cline { 2 - 4 } & $5 \mathrm{~min}$ & $30 \mathrm{~min}$ & $5.2 \times 10^{8}$ \\
\hline Control & 4.95 & 2.28 & 0 \\
\hline
\end{tabular}



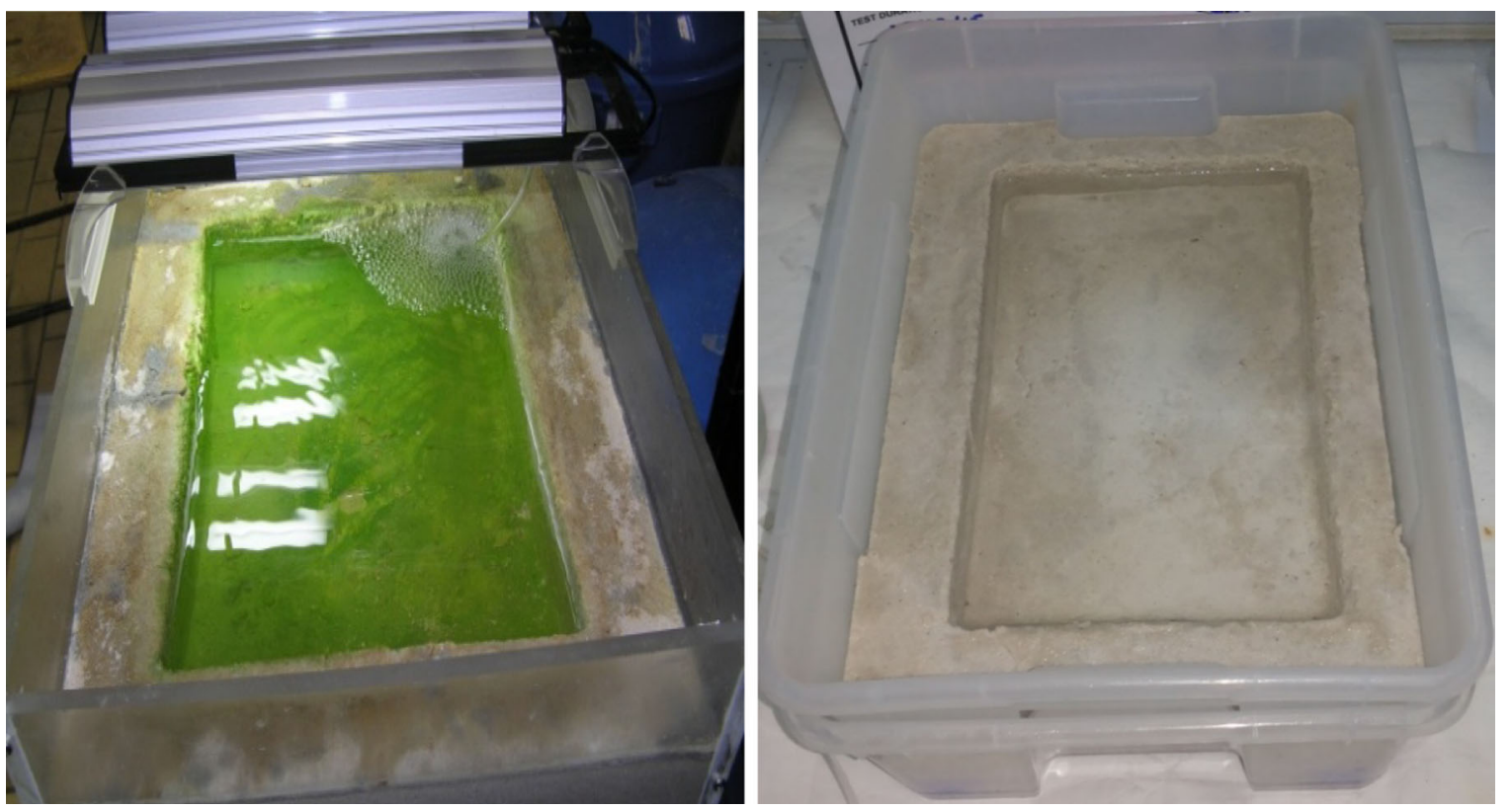

Fig. 2 Images of model ponds constructed in sand using live cells of urease-producing bacteria Bacillus sp. VS1 (left image, bottom is coated with the grown biofilm of algae) and dead but urease active cells of Yaniella sp. VS8 (right image)
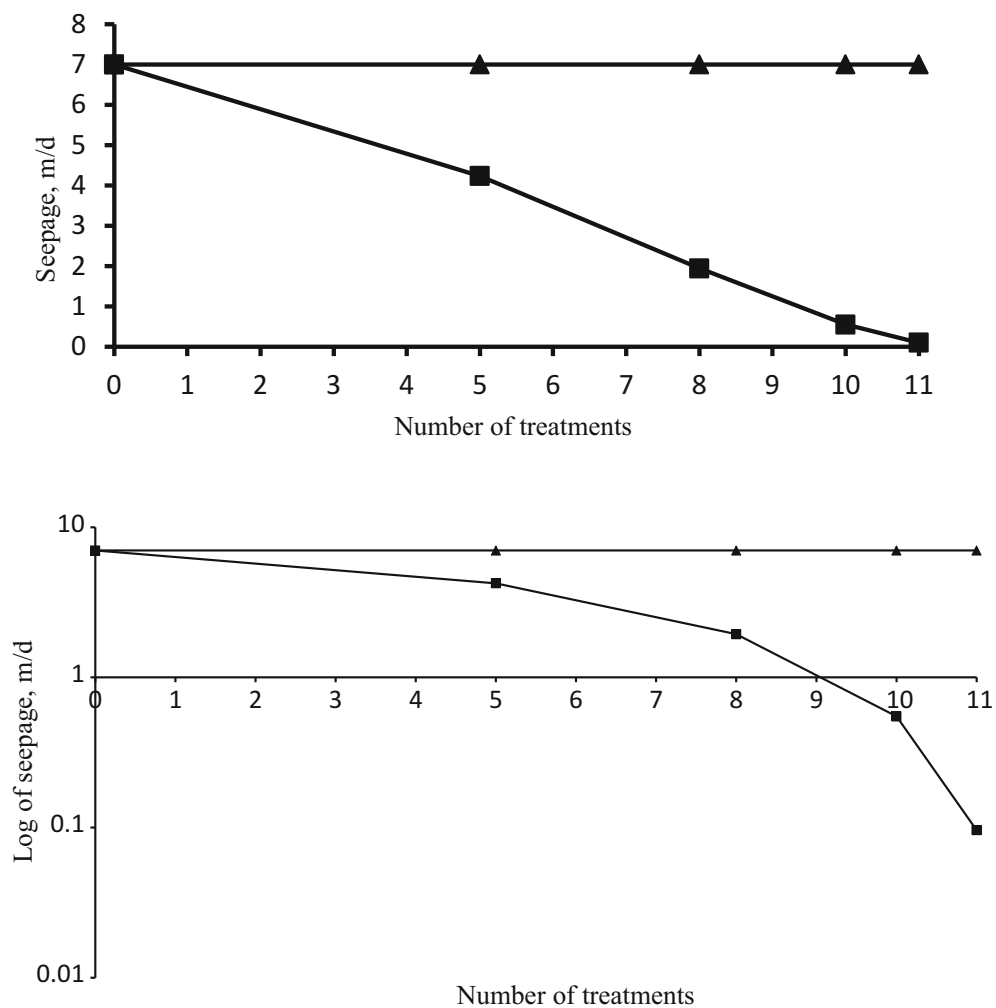

Fig. 3 Dynamics of bioclogging with $\mathrm{CaCO}_{3}$ (in linear and logarithm scales). Rectangles show experimental treatment with dead but urease-active bacteria, triangles show control treatment without bacteria

The content of live microbial cells in the sample taken from the pond surface was $4 \times 10^{2} \mathrm{CFU} / \mathrm{g}$ of the biocemented sand, which is almost the same as initial bacterial contamination of sand, $1.1 \times 10^{2} \mathrm{CFU} / \mathrm{g}$. 


\section{Quality of water after biotreatment}

Initial water was tap water with electric conductivity $0.35 \mathrm{mS}$. The model pond produced after bioclogging and drying was washed with tap water three times for about $12 \mathrm{~h}$ of each washing. After that, the electrical conductivity and concentrations of dissolved calcium and magnesium were studied (Table 2).

Meanwhile, effluent accumulated after $16 \mathrm{~h}$ of seepage had the same $\mathrm{pH} 7.8$, but significantly higher electric conductivity of $2.54 \mathrm{mS}$, and concentrations of $\mathrm{Ca}^{2+}$ and $\mathrm{Mg}^{2+}$ were 2.65 and $0.12 \mathrm{mM}$, respectively. Ammonium was not determined in water of the model pond but accumulated in effluent up to $2.7 \mathrm{mM}$. Probably, calcium, magnesium, and ammonium ions were extracted from a layer of not biocemented sand, which was under a layer of sand that was cemented with calcium carbonate.

Biosealing of sand with iron hydroxide

Solution of ferrous ions can be produced from iron ore and cellulose for about 4-10 days in batch anaerobic cultivation (Fig. 4).

To create anaerobic conditions, the diffusion of oxygen from air was prevented by an addition of sand into the reactor with iron ore and cellulose. Strong anaerobic conditions with oxidation-reduction potential $-320 \mathrm{mV}$ were self-developed at 5-6 cm depth below sand surface by bacterial community. $\mathrm{pH}$ of effluent was 6.5 with concentration of $\mathrm{Fe}^{2+}$ above $0.5 \mathrm{~g} / \mathrm{L}$.

Produced solution of soluble ferrous salts was supplied to the sand column for bioclogging by dropping through air, so percolation of sand was by aerated ferrous-containing grout. $\mathrm{pH}$ of liquid increased after the treatment of sand with a mixture of this grout, $0.05 \mathrm{M}$ urea solution and suspension of UPB to 8.5 with almost complete precipitation of iron when final concentration of $\mathrm{Fe}^{2+}$ was below $5 \mathrm{mg} / \mathrm{L}$. After ten treatments, the hydraulic conductivity of sand decreased from $5 \times 10^{-4}$ to $1 \times 10^{-6} \mathrm{~m} / \mathrm{s}$. The pores of sand were visibly filled with brown ferric hydroxide (Fig. 5).

Table 2 The electric conductivity and concentrations of dissolved calcium and magnesium in water after treatment and washing of the model pond

\begin{tabular}{lllll}
\hline $\begin{array}{l}\text { Time after filling of the model } \\
\text { pool with water }(\mathrm{h})\end{array}$ & $\mathrm{pH}$ & $\begin{array}{l}\text { Electric conductivity } \\
(\mathrm{mS})\end{array}$ & $\mathrm{Ca}^{2+}(\mathrm{mM})$ & $\mathrm{Mg}^{2+}(\mathrm{mM})$ \\
\hline 0 & 7.9 & 0.35 & 0.30 & 0.02 \\
4 & 7.8 & 0.49 & 0.45 & 0.02 \\
24 & 7.9 & 0.50 & 0.65 & 0.02 \\
28 & 8.0 & 0.57 & 1.35 & 0.04 \\
100 & 8.1 & 0.74 & 1.58 & 0.05 \\
\hline
\end{tabular}

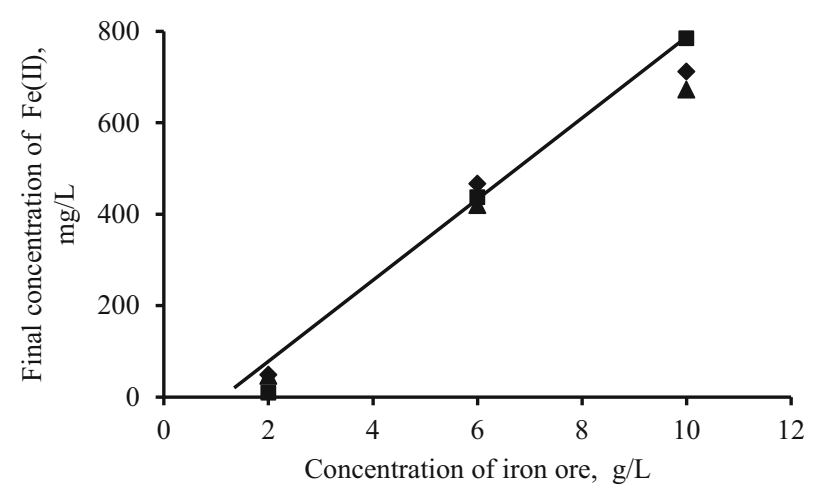

Fig. 4 Production of Fe(II) in experiments with different concentrations of iron ore at the following concentrations of cellulose: $2 \mathrm{~g} / \mathrm{L}$ (filled rhombus); $6 \mathrm{~g} / \mathrm{L}$ (filled square); $10 \mathrm{~g} / \mathrm{L}$ (filled triangle) 


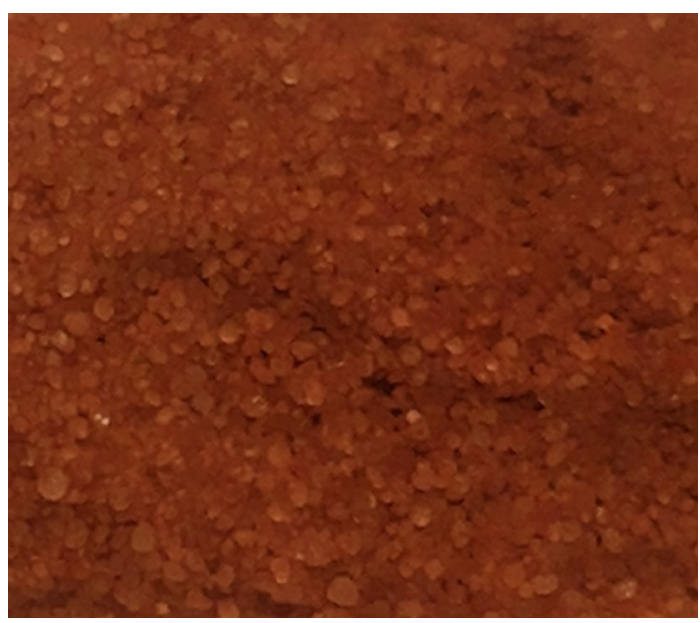

Fig. 5 Sand after bioclogging with iron-based biogrout

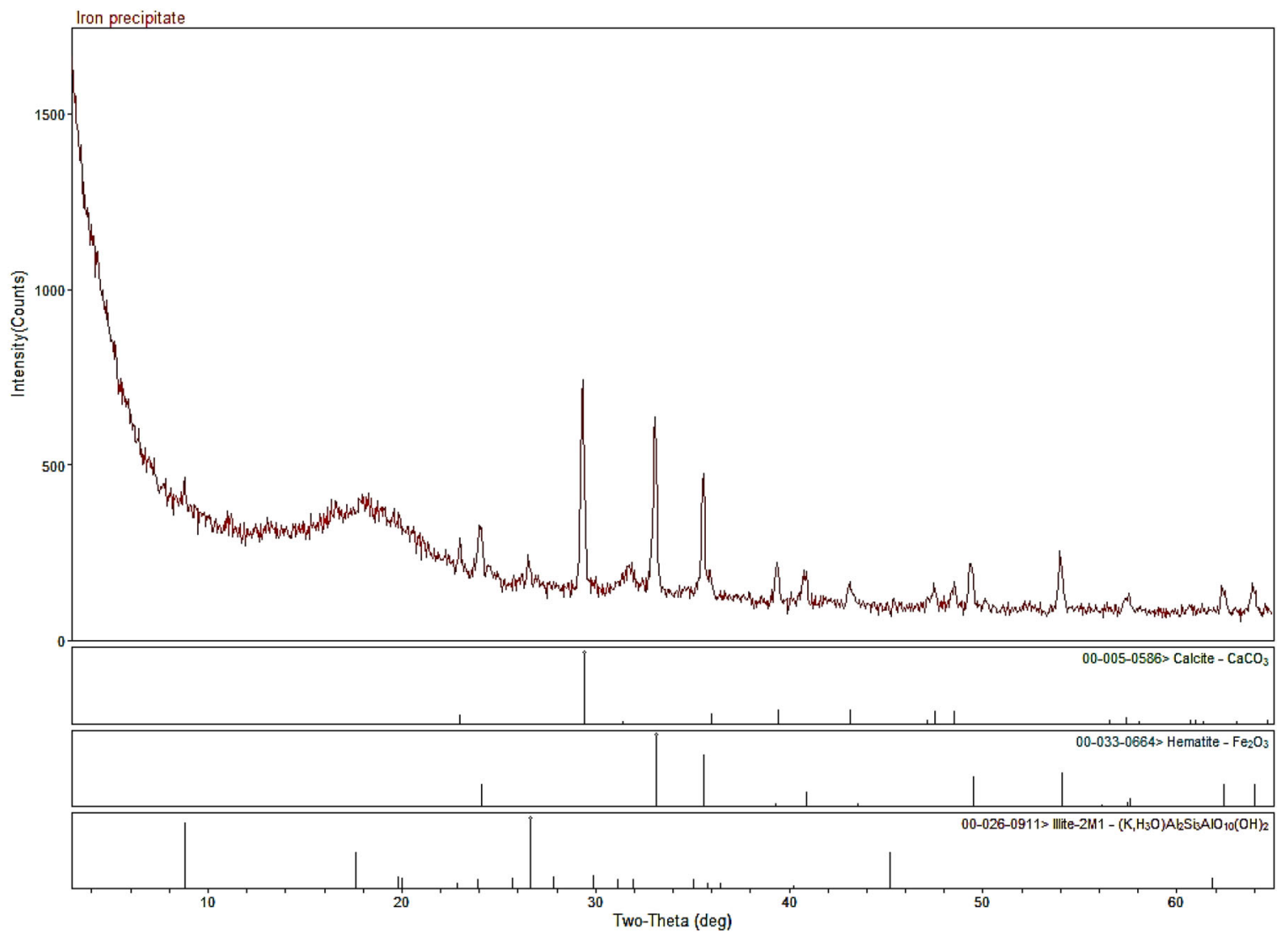

Fig. 6 XRD of the material precipitated in sand

XRD of the material precipitated in sand shows that this precipitate was a mixture of hematite and calcite (Fig. 6).

Treatment of sand with iron-based biogrout did not increase the unconfined compressive strengths of the treated sand significantly. Therefore, major application of iron-based biogrout produced from iron ore and cellulose could be bioclogging of the porous soils for the sealing of aquaculture ponds or the fractured sedimentary rocks during the dam or tunnel construction. 


\section{Comparison of the sand biosealing with other methods}

The calculated consumptions of biomass, calcium, and urea per $1 \mathrm{~m}^{2}$ of cemented sand surface were as follows: $0.08 \mathrm{~kg}$ of dry bacterial biomass; $1.5 \mathrm{~kg}$ of calcium $\left(4.1 \mathrm{~kg}\right.$ of $\left.\mathrm{CaCl}_{2}\right) ; 3.1 \mathrm{~kg}$ of urea. Considering that the costs of dry calcium chloride, urea, and bacterial suspension are about US $\$ 250$, US $\$ 360$, and US $\$ 500$ per ton, respectively, the evaluated total cost of the calcium chloride-based biosealing materials is about US $\$ 18,000$. It is lower than the cost of the sealing with bentonite, US\$48,000/ha, and is significantly lower than sealing cost with geosynthetic liners, which is about US $\$ 100,000 / \mathrm{ha}$.

The sealing of sand (i.e., formation of 10-cm layer of sand with the content of iron oxide $5 \%$ w/w) with iron-based biogrout produced from iron ore and waste cellulose from municipal solid waste, agricultural waste, and food-processing wastes will require per $1 \mathrm{~m}^{2}$ of cemented sand surface $0.08 \mathrm{~kg}$ of dry bacterial biomass; $8 \mathrm{~kg}$ of iron oxide (hematite iron ore), $3 \mathrm{~kg}$ of urea, and $1 \mathrm{~kg}$ of waste cellulose. Considering that the costs of iron ore dry iron ore, urea, bacterial biomass, and waste cellulose are about US\$100, US\$360, US\$500, and US\$100 per ton, respectively, the evaluated total cost of the iron ore-based biosealing materials is about US\$23,800. It is also lower than the cost of known sealing materials. The cost of this sealing could be especially low when the local sources of calcium chloride brain can be used.

\section{Scale-up factors}

Theoretical comparison of the supplies of urea, which is a major component of the biosealing composition, using Eqs. 1 and 2 for calcium chloride-based biosealing (density of calcite is $2.71 \mathrm{~g} / \mathrm{cm}^{3}$ ) and iron ore-based biosealing (density of ferric hydroxide is $4.25 \mathrm{~g} / \mathrm{cm}^{3}$ ) are $0.221 \mathrm{~g} \mathrm{urea} / \mathrm{cm}^{3}$ of porous space in sand and $0.396 \mathrm{~g} \mathrm{urea} / \mathrm{cm}^{3}$ of porous space in sand, respectively. So, calcium chloride-based biosealing requires almost twice bigger quantity of urea per volume of the porous space than iron ore-based biosealing method needs. Respectively, twice bigger quantity of ammonium will be released to environment in case of iron ore-based biosealing. Therefore, selection of the most suitable scaled-up application must be based on both economy and environmental considerations, as well as on the local availability of either sources of calcium salts, for example, underground calcium chloride brain, or iron ore, especially its fine powder, which is most suitable for bioreduction of iron (III).

Important scale-up factor is the thickness of the biosealing layer which has to be sufficiently mechanically strong to prevent cracking because of the bending from hydraulic head and/or thermal expansion. This thickness must be determined in the field tests at the defined area at the different water heads and solar radiation. In every case, it will not be bigger than several centimeters.

The hydraulic conductivity and strength after biotreatment is determined by the third, and probably the major scale-up factor, which is the content of precipitated $\mathrm{CaCO}_{3}$. In our experiments, the contents of $\mathrm{CaCO}_{3}$ in sand were $45,6,8$, and $8 \%(\mathrm{w} / \mathrm{w})$ on the distance $1,2,3$, and $4 \mathrm{~cm}$ from surface of the bottom, while there were 13 and $19 \%$ of $\mathrm{CaCO}_{3}$ on the distance of $1-2 \mathrm{~cm}$ from the top and side surfaces of the wall.

The seepage rate from the model pond was $96 \mathrm{~mm} /$ day at the content of calcium in $1 \mathrm{~cm}$ layer on the bottom 45 and $18 \%(\mathrm{w} / \mathrm{w})$ in $1 \mathrm{~cm}$ layer of the side surface of the wall. This seepage was almost the same as the seepage rate from the model pond constructed in sand using un-inactivated cells of UPB Bacillus sp. VS1, when an average $2.1 \mathrm{~kg}$ of calcium per $\mathrm{m}^{2}$ of sand surface was precipitated (Stabnikov et al. 2011; Chu et al. 2013). These seepage rates are comparable with the seepage rates for the aquaculture ponds (TeichertCoddington et al. 1989; Weisburd and Laws 1998).

The technology with sprayed calcium-based biogrout simplifies considerably the procedure, because there is no use of live microorganisms and thus there is no need for the numerous and complicated biosafety approvals needed for the real construction projects. The technology with percolated iron-based biogrout simplifies considerably the production of the sealing materials, because raw materials, low-grade iron ore and cellulose-containing waste, need for construction are abundant everywhere. However, essential part of the sand biogrouting is drying of the treated sand under sun light. Our data showed that this drying removes ammonia and ammonium from the treated sand, which is essential for fish and prawns aquaculture, but not favorable for algae cultivation. Sand sealed with iron-based biogrout is more mechanically stable for drying under sun light than sand treated with calcium-based biogrout. In the last case, the treated sand is more brittle 
and there is possible the formation of fine cracks due to thermal expansion of the treated sand. Repair of these cracks requires additional treatment of sand after sun light drying.

Major limitation of the proposed biosealing method of the sand pond is the release of ammonia to atmosphere and ammonium to water, which can produce toxic effects for human being, animals, fishes and prawns. So, the best solution is the use of the constructed pond for the cultivation of oil-producing algae in the coastal desert area. Then, when ammonium will be washed out from the cemented sand and consumed by the oil-producing algae during one or several cycles of their cultivation, the pond could be used for the fish aquaculture. There must be a source of carbon dioxide for algae growth, so additional layer of calcium carbonate on the bottom of the pond can be a source of carbon dioxide as well as a source of calcium ions for further strengthen and biosealing of the pond bottom.

In conclusion, because the cost of biosealing of sand using calcium chloride- or iron ore-based biogrouts could be several times lower than any other known methods of the sand sealing, the biosealing has to be test in aquaculture practice for the construction of fish, prawns, or algae ponds in sand of the arid deserts.

Acknowledgments This research was supported in part by the Ministry of National Development, Singapore, as MND-NTU joint R\&D "Biogrouting for underground construction-a new technology to maximize the usage of underground space in Singapore" (Grant No. SUL2013-1), by Visiting Professor Fellowship, Department of Civil, Construction and Environmental Engineering, Iowa State University, USA. The authors acknowledge support for the studies of different aspects of iron bioreduction, oxidation and precipitation, which commercial applications are protected in general by US Patent 7393452 and Patent of Singapore 106658, from The Enterprise Challenge Fund of Prime Minister's Office, Singapore; Agency of Science and Technology (A*STAR), Singapore; Public Utilities Board, Singapore; as well as Professorship Program support from National University of Food Technologies, Kiev, Ukraine.

Open Access This article is distributed under the terms of the Creative Commons Attribution 4.0 International License (http:// creativecommons.org/licenses/by/4.0/), which permits unrestricted use, distribution, and reproduction in any medium, provided you give appropriate credit to the original author(s) and the source, provide a link to the Creative Commons license, and indicate if changes were made.

\section{References}

Adamowicz M, Kelley PM, Nickerson KW (1991) Detergent (sodium dodecyl sulfate) shock proteins in Escherichia coli. J Bacteriol 173:229-233

Al-Thawadi S, Cord-Ruwisch R (2012) Calcium carbonate crystals formation by ureolytic bacterial isolated from Australian soli and sludge. JASER 2:12-26

Bachmeier KL, Williams AE, Warmington JR, Bang SS (2002) Urease activity in microbiologically-induced calcite precipitation. J Biotechnol 93:171-181

Bang SS, Galinat JK, Ramakrishnan V (2001) Calcite precipitation induced by polyurethane-immobilized Bacillus pasteurii. Enzyme Microb Technol 28:404-409

Burbank MB, Weaver TJ, Green TL, Williams BC, Crawford RL (2011) Precipitation of calcite by indigenous microorganisms to strengthen liquefiable soil. Geomicrobiol J 28:301-312

Burbank MB, Weaver TJ, Williams BC, Crawford RL (2012) Urease activity of ureolytic bacteria isolated from six soils in which calcite was precipitated by indigenous bacteria. Geomicrobiol J 29:389-395

Chu J, Stabnikov V, Ivanov V (2012) Microbially induced calcium carbonate precipitation on surface or in the bulk of soil. Geomicrobiol J 29:1-6

Chu J, Ivanov V, Stabnikov V, Bi L (2013) Microbial method for construction of aquaculture pond in sand. Géotechnique 63:871-875

De Muynck W, De Belie N, Verstraete W (2010) Microbial carbonate precipitation in construction materials: a review. Ecol Eng 36:118-136

DeJong J, Fritzges M, Nusstein K (2006) Microbially induced cementation to control sand response to undrained shear. J Geotech Geoenviron Eng 132:1381-1392

DeJong JT, Mortensen BM, Martinez BC, Nelson DC (2010) Bio-mediated soil improvement. Ecol Eng 36:197-210

Dosier GK (2014) Methods for making construction material using enzyme producing bacteria. US Patent 8728365 B2

Dupraz S, Parmentier M, Ménez B, Guyot F (2006) Experimental and numerical modeling of bacterially induced pH increase and calcite precipitation in saline aquifers. Chem Geol 265:44-53

Elmanama AA, Alhour MT (2013) Isolation, characterization and application of calcite producing bacteria from urea rich soils. J Adv Sci Eng Res 3:388-399

Ferris FG, Stehmeier LG, Kantzas A, Mourits FM (1996) Bacteriogenic mineral plugging. J Can Pet Technol 35:56-61

Flahaut S, Frere J, Boutibonnes P, Auffray Y (1996) Comparison of the bile salts and sodium dodecyl sulfate stress responses in Enterococcus faecalis. Appl Environ Microbiol 62:2416-2420

Gat D, Tsesarsky M, Shamir D, Ronen Z (2014) Accelerated microbial-induced $\mathrm{CaCO}_{3}$ precipitation in a defined coculture of ureolytic and non-ureolytic bacteria. Biogeosciences 11:2561-2569 
Hansen JS, Vararattanavech A, Plasencia I, Greisen PJ, Bomholt J, Torres J et al (2011) Interaction between sodium dodecyl sulfate and membrane reconstituted aquaporins: a comparative study of spinach SoPIP2;1 and E. coli AqpZ. Biochimika et Biophysica Acta (BBA)-Biomembranes 1808:2600-2607. doi:10.1016/j.bbamem.2011.05.021

Ivanov V, Chu J (2008) Applications of microorganisms to geotechnical engineering for bioclogging and biocementation of soil in situ. Rev Environ Sci Biotechnol 7:139-153

Ivanov V, Chu J, Stabnikov V (2015) Basics of construction microbial biotechnology. In: Pacheco-Torgal F, Labrincha JA, Diamanti MV, Chang PY, Lee HK (eds) Biotechnologies and Biomimetics for Civil Engineering. Springer International Publishing, Switzerland, pp 21-56

Khanafari A, Khans FN, Sepahy AA (2011) An investigation of biocement production from hardwater. Middle-East J Sci Res 7:1990-9233

Kramer VC, Nickerson KW, Hamlett NV, O'Hara C (1984) Prevalence of extreme detergent resistance among the enterobacteriaceae. Can J Microbiol 30:711-713

Madigan MT, Martinko JM, Bender KS, Buckley DH,Stahl DE, Brock T (2014) Brock Biology of Microorganisms, 14 ed. Benjamin Cummings, Upper Saddle River, New Jersey

Maheswaran S, Dasuru SS, Murthy ARC, Bhuvaneshwari B, Kumar VR, Palani GS, Iyer NR, Krishnamoorthy S, Sandhya S (2014) Strength improvement studies using new type wild strain Bacillus cereus on cement mortar. Cur Sci 106:50-57

Mortensen B, DeJong J (2011) Strength and stiffness of MICP treated sand subjected to various stress paths. In: Han J, Alzamora DA (eds) ASCE Geo-Frontiers, ASCE, pp 4012-4020 doi: 10.1061/41165(397)410

Rong H, Qian CX, Li LZ (2012) Influence of molding process on mechanical properties of sandstone cemented by microbe cement. Constr Build Mater 28:238-243

Stabnikov V, Chu J, Naeimi M, Ivanov V (2011) Formation of water-impermeable crust on sand surface using biocement. Cement Concrete Res 41:1143-1149

Stabnikov V, Chu J, Ivanov V, Li Y (2013) Halotolerant, alkaliphilic urease-producing bacteria from different climate zones and their application for biocementation of sand. World J Microb Biotechnol 29:1453-1460

Stabnikov V, Ivanov V, Chu J (2015) Construction biotechnology: a new area of biotechnological research and applications. World J Microb Biotechnol 31:1303-1314

Stocks-Fischer S, Galinat JK, Bang SS (1999) Microbiological precipitation of $\mathrm{CaCO}_{3}$. Soil Biol Biochem 31:1563-1571

Teichert-Coddington DR, Peralta M, Phelps RP (1989) Seepage reduction in tropical fish ponds using chicken litter. Aquac Eng 8:147-154

Tobler DJ, Cuthbert MO, Phoenix VR (2014) Transport of Sporosarcina pasteurii in sandstone and its significance for subsurface engineering technologies. Appl Geochem 42:38-44. doi:10.1016/j.apgeochem.2014.01.004

Varalakshmi AD (2014) Isolation and characterization of urease utilizing bacteria to produce biocement. IOSR-JESTFT 8:52-57

Weisburd RSJ, Laws EA (1998) Free water productivity measurements in leaky mariculture ponds. Aquac Eng 9:175-188

Whiffin VS (2004) Microbial $\mathrm{CaCO}_{3}$ precipitation for the production of biocement. PhD Thesis, Murdoch University, Perth, Australia

Whiffin VS, van Paassen LA, Harkes MP (2007) Microbial carbonate precipitation as a soil improvement technique. Geomicrobiol J 24:17-423

Winckelmann D, Bleeke F, Thomas B, Elle C, Klock G (2015) Open pond cultures of indigenous algae grown on non-arable land in an arid desert using wastewater. Int Aquatic Res 7:221-233

Woldringh CL, Van Iterson W (1972) Effects of treatment with sodium dodecyl sulfate on the ultrastructure of Escherichia coli. J Bacteriol 111:801-813 